\title{
A case study of science teacher candidates' understandings and actions related to the culturally responsive teaching of 'Other' students
}

\author{
Mary M. Atwater, Tonjua B. Freeman, Malcolm B. Butler, Jessie Draper-Morris
}

Received 23 November 2009; Accepted 13 March 2010

\begin{abstract}
The purpose of this explanatory case study using critical theory as a philosophical lens was to focus on two science teacher candidates' understandings of Otherness and their culturally responsive teaching (or the lack thereof) of students they believe are the 'Others'. The researchers found that even though the participants had different goals for their students, they were not responsive to some of their students because of the students' culture, race, and/or ethnicity. Both of the participants believed their science teacher education program had shortcomings and did not provide all of the needed experiences for them to be successful in their science teaching of the 'Other' students.
\end{abstract}

Keywords: multicultural science teacher education, culturally responsive teaching, critical theory, case study

\section{Introduction}

We need research that examines the links among teacher preparation for diversity, what teacher candidates learn from this preparation, how this affects their professional practices in schools, and what the impact is on pupils' learning (Hollins \& Guzman, 2005, p. 512).

What and how student teachers learn in their teacher preparation program is strongly influenced by their existing knowledge and beliefs; therefore, challenging these through creating dissonance is one way of generating opportunities for new learning (Loughran, 2007, p. 1045).

Conceptual and methodological research is needed to provide empirical evidence about teacher preparation if sound policies and practices are to be executed. There are a variety of ways people are prepared to be teachers in the United States. With the shortage of mathematics, science, foreign language, and special education teachers and the increase in cultural diversity among students in the United States, it has become imperative to study one of the most significant factors in students' learning - the teacher (Cochran-Smith \& Zeichner, 2005). 
Teachers' dispositions, preservice preparation of prospective teachers, the experiences of teacher candidates of color, and the evaluation of teacher preparation programs have been the focus of past research studies (Aikenhead \& Otsuji, 2000; Atwater \& Crockett, 2003; CroninJones, 1991; Jones \& Carter, 2007; Hollins \& Guzman, 2005; Luft, 2001; Tatto, 1998; Zint, 2002; Thomson, Wilder, \& Atwater, 2001). For instance, researchers like Banks (1973), Cochran-Smith, Davis, and Fries (2004), Darling-Hammond and Sclan (1996), Haberman (1996), Ladson-Billings (1994), Grant and Secada (1990), Nieto (1992), Sleeter (1992), and Zeichner (1992) have called for a research base for preparing teachers to be effective in teaching traditionally underrepresented student populations and students in traditionally underserved areas. Our study focuses on two secondary science teacher candidates' understanding of Otherness, particularly as it relates to culture, race, and ethnicity and the ways they culturally teach these students in their science classrooms. Hence, the researchers sought to answer the following questions:

1. How important is it to the participants to culturally teach students they believe are 'Others' in their teaching?

2. What kind of experiences, if any, have the participants had in which they witnessed their mentor science teachers and their former teachers culturally teaching their students they believe are 'Others'?

3. What instructional changes/accommodations, if any, did the participants make to culturally teach students they believe are 'Others' and why?

4. What recommendations did the participants make to restructure science teacher education programs to better prepare future teachers to teach students who are different from them?

\section{Review of Pertinent Research}

Research findings on the preparation of teachers for Asian, Black, Latino, Native American, and English Language Learner students have been examined and analyzed in a number of syntheses (Cochran-Smith, Davis, \& Fries, 2004; Darling-Hammond, 2000; Garcia, 1995; Grant \& Secada, 1990; Haberman, 1996; Sleeter, 2001a, 2001b; Weiner, 1993, 2000; Zeichner \& Hoeft, 1996). Much evidence exists about the wide disparity in teachers' experiences based on their social-class backgrounds and the social-class designations of their students. This disparity affects teachers' expectations for their students' optimal learning (Spencer, 2001). Metz (1986) and Haberman (1996) found that the socioeconomic backgrounds of teachers and the perceived differences in their students' attitudes, lifestyles, and social networks define both their work and their responses to their students. When teachers and students had similar backgrounds, teachers were more likely to understand their students. If there was not a foundation for the teachers and their students to share, then tensions and barriers in communication grew and beliefs about the "Others" were incorporated into the school culture and passed along to new teachers (Haberman, 1996; Metz, 1986). 


\section{Other}

The term "Other" is a term that is crucial to understanding the cultural system in which a group of people live. It is embedded in the idea of alterity, which has a primary meaning of the "state of being otherwise" (Grant \& Sleeter, 1997). Otherness helps to define through negation the criterion of being or of what specific culture is good and bad. People of a certain group occupy a position of the stigmatized category of Otherness. As a result of the transformation of the cultural system in the United States, Whites and people of color (Africans, African Americans, Asians, Asian Americans, Latinos, and Native Americans) are viewed as the dominant and the nondominant groups "dominant and the non-dominant groups, respectively". The dominant group ideologies are seen as right, proper and privileged and thus to be used to subjugate the members of the non-dominant groups to be the same. Using this framework, the dominant ideologies embody power and influence educational policies and practices in the United States. Both the content of education, including science education, and its systems play an important part in regulating and defining students in comparison to a perceived norm. Of course, the norm is established by the dominant group. When the 'Other' students are not being excluded in terms of science content, attempts are made to mold them into students that learn the same prescribed, unquestioned, and sometimes oppressive science content that do not assist them in changing their worlds around them. The 'Other' students are diminished, marginalized, and labeled so that they do not fit into the norm (Cohen, 2006; Hall, 1992; McLaren, 1995; Smith, 1992).

\section{Culture}

Ladson-Billings (2004) maintains that there is limited thinking about the term "culture." Lee and Slaughter-Defoe (2004) define culture as acquired knowledge used by people to interpret their experiences and cause their behaviors, which is transmitted through language. This knowledge includes their "understandings about social roles and relationships, structures for communicating norms about what is appropriate to be communicated to whom and under what circumstances, and conceptions about the natural world and [their] roles in it" (p. 472). Hence, language is an essential tool through which people, including teacher candidates, communicate, but also construct their knowledge and think about new problems they encounter. According to Hamilton (1996), culture has two definitional perspectives. The first is in general terms, that is, it is the "shared perceptions of class, race, and ethnicity blended with personal experiences to represent the world" (p. 186). The second perspective defines culture in terms of schooling as "school culture": "the experiences that shape teachers' understanding of their actions" (p. 186). It is the second definition that the researchers of this study utilized in this case study.

\section{Race}

Race does matter in the United States (West, 1993); therefore many social scientists concur that race is a socially constructed category for human beings (Bonilla-Silva, 2006; Grant \& LadsonBillings, 1997). However, there are a few scholars such as Arthur Jensen (1998) and Richard Herrnstein and Charles Murray (1994) that still believe race is a biological category to group people in a hierarchical fashion into superior and inferior groups. Those supporting this latter view, usually those from the dominant power group, regard themselves as superior and the norm, while groups different in physical and language traits from the dominant group are deemed inferior.

In a study by Johnson (2002), six White female teachers were aware of physical differences, had a growing political awareness of race, and did not acknowledge themselves as racial beings, 
especially those who were from poor and working-class backgrounds. Johnson (2002) found that teachers' perceptions of racial awareness were influenced by (a) their perceived identity as "outsider" due to their social class background or sexual orientation (b) living and working with individuals of color in situations where the individuals were in equal status so the teachers got an "insider's" perspective on race and racism, and (c) their personal philosophical beliefs or their religious beliefs that emphasized equality and social justice. However, most of Jones' participants (six White female teachers) still saw race in a Black-White paradigm and mostly noticed cultural differences only in Latino and Native American students.

\section{Ethnicity}

Grant and Ladson-Billings (1997) believe that the general populace associates ethnicity with different groups who are either physically or culturally different from the dominant group's culture and physical characteristics. Hence, many people believe that the word ethnicity should be ascribed to people of color and those whose second language is English. An ethnic group is usually established when a group of people view themselves as having common attributes and who are willing to call themselves an ethnic group or are labeled as an ethnic group by the dominant society - for example European Americans and Latinos with African ancestry, respectively (Rotheram \& Phinney, 1987). Ethnic categories are socially constructed and the social definitions of these categories have changed over time (Alba, 1990; Cross, 1971; Hardiman, 2003; Helms, 1990; Ponterotto, Caas, Suzuki, \& Alexander, 1995; Tajfel, 1978).

\section{Social Class}

In many schools in which "poor kids" enroll, these students perform poorly (Chenoweth, 2007). According to Grant and Ladson-Billings (1997), class is a construct about economic, social, and political relationships that control life in a given social order. In schools, just as in societies, student social class is used to constrain and limit them in having the opportunity to engage in quality science learning. Student social class dictates students' access to power and its structural allocations such as human resources and learning materials. These events usually happen in rural, city-like, and urban schools with a large percentage of students of color on reduced and free lunch. In other words, teachers view them as the 'Other' students.

\section{Intersections among Culture, Race, Ethnicity, and Social Class}

Researchers have identified the positionality of teachers as important factors in the classroom (Banks \& Banks, 1989; Brown, 1998; Brown, Cervero, \& Johnson-Bailey, 2000; Parsons, 2000; Sleeter \& Grant, 2007). The primary identifiers are race, ethnicity, culture, gender, class, physical ability and sexual identity. In this study, race, ethnicity, and culture are the important identifiers that were considered since they also define students, and the idea of 'Otherness' (Grant \& Ladson-Billings, 1997). Barton (2007) maintains that urban Black students not only do not achieve well in science compared to their White counterparts, but that science learning in urban classrooms is embedded with power relations that frame who is considered scientific or capable of learning science. Questions should be raised about the role of teachers' understandings of culture and how these understandings play in their abilities to prepare students to be successful within the culture of science (Barton, 2007). 


\section{Beliefs, Attitudes, and Understandings}

Experiential knowledge and the acquisition of this knowledge are important in understanding how preservice and inservice teachers develop teacher knowledge, especially in debunking the idea that good teaching is about acquiring skills (Munby, Russell, \& Martin, 2001). Teacher beliefs and assumptions about good teaching rarely change during the course of a teacher education program (Richardson \& Placier, 2001). Consequently, it is important to understand how experiences about the practices of teaching impact teachers' willingness to culturally respond to their students' needs.

In the most recent publication of the Handbook of Research on Science Education, Jones and Carter (2007) discussed science teacher attitudes and beliefs. They maintain that teachers' beliefs and attitudes shape their understandings, judgments, and actions in science classrooms. Using a sociocultural model of embedded belief systems, they summarized the research findings on teacher beliefs, attitudes, and instructional decisions and actions in science classrooms. Preservice science teachers enter into teacher education programs with ideas, images, and models of teaching, many of which are based upon their past experiences. Since the sociocultural contexts of teaching are influenced by the culture of the teachers and students, it is not surprising that teachers' dispositions, beliefs, and attitudes about their students' cultures, races, and ethnicities shape instructional actions in the classrooms (Bryan \& Atwater, 2002). However, preservice and inservice teachers' belief systems are slow to change (Martin \& William-Dixon, 1994). This is manifested in their interactions with students, the strategies they use for instruction, their classroom management systems, their selection of what to teach, and their assessment and evaluation practices (Jones \& Carter, 2007).

According to Abell (2007), there have been studies on teacher planning that examined science teachers to better understand how science teachers plan and what knowledge and beliefs influence their planning. However, few studies have examined science teachers' knowledge, beliefs, and understandings that influence their willingness to culturally teach their students and the changes they have made in their science teaching due to their students' culture, race, or ethnicity (Lee \& Luykx, 2007). Hence, in this study, the researchers are interested in the adjustments made by science teacher candidates in their curriculum, instruction, assessment, and evaluation so that all of their students will experience quality science learning. These adjustments may be the result of the students' experiences due to oppression, disenfranchisement, and/or marginalization due to race, culture, and/or ethnicity.

\section{Culturally Responsive Teaching}

Culturally responsive teaching is based on the supposition that when academic knowledge and skills are situated within the lived experiences and frames of reference of students, they are more personally meaningful, have higher interest and appeal, and are learned more easily and thoroughly (Gay, 2000). According to Gay (2002), it is the employment of cultural characteristics, experiences, and perspectives of students as conduits for effective teaching. Since most science teachers in the United States are White and middle class (Peng, Wright, \& Hill, 1995; Wayne \& Young, 2003), the norm for teaching does not necessarily embrace culturally responsive teaching. Gay (2002) maintains that effective teaching requires teachers to have the following: (a) a developed cultural diversity knowledge base, (b) the capability to develop culturally relevant curricula, (c) the ability to build a learning environment in which caring and cultural scaffolding occur, (d) the ability to conduct cross cultural communications, and the (e) knowledge and skills to match instruction to the students from a variety of cultures. Likewise, Irvine (2003) argues that teachers who teach students who are different from them must be 
culturally sensitive, view teaching as a calling, have a sense of shared identity with their students, care about their students deeply, advocate for their students, and be "dreamkeepers."

Most teacher educators indicate that students resist multicultural education. Brown (2004) investigated the relationship between instructional methodology and changes in resistance to cultural diversity sensitivity among White teacher education students in a required junior-level cultural diversity course. She used the Cultural Diversity Awareness Inventory (CDAI) as a pretest and posttest empirical measure, entries in reflective journals, field experience reports, and research projects to detect incremental changes in the thinking of her students. The results indicated that the message that knowing about student cultural diversity is important can precipitate some change in cultural diversity sensitivity, but self-examination, participation in cross-cultural field experiences, and active engagement in cross-cultural research reduced resistance and helped the students to comprehend the effects of "minority" culture status. Teacher education programs that desire their graduates to be more sophisticated in their understanding of the effects of context and learner variability on teaching and learning are using cases, exhibits, portfolios, and problem-based inquiries to determine their students' capability of teaching students who are different from them (Darling-Hammond \& Snyder, 1998).

\section{Theoretical Frameworks}

\section{Philosophical Perspective: Critical Theory}

The goal of critical theory is to "uncover hidden assumptions that govern society - especially those about the legitimacy of power relationships - and it debunks or deconstructs their claim to authority" (deMarrais \& LeCompte, 1995, p. 25). Using the ideas of Kincheloe and McLaren (1994), the researchers of this study want this investigation to be a form of social or cultural criticism. They embrace the following basic assumptions: (a) all thought is mediated by power relationships, especially in teaching situations, that are social in nature and historically constituted, (b) language is central to the formation of conscious and unconscious awareness and actions, (c) certain groups in any human society such as teachers are privileged over other groups such as the 'Other' student which can cause oppression, and (d) oppression has many faces, especially in science classrooms (Kincheloe \& McLaren, 1994). Hence, the investigation of prospective science teachers using critical theory is a legitimate way to uncover the ways in which ideas, understandings, and actions will be translated and are translated to maintain the dominant group's ideologies about 'Others' and the disenfranchisement of certain students in science learning. For instance, students do have the right to be taught in a manner so they have the opportunity to experience quality science teaching. The culturally responsive teaching that science teacher candidates are willing to do and actually do in classrooms is essential in understanding if the 'Other' students have the opportunity to learn quality science. Using critical theory as a lens, the researchers are better able to understand the culturally responsive science teaching, if any, that teachers are willing to do and why teachers do or do not culturally respond in their teaching to their 'Other' students. The researchers sought to investigate patterns of unexamined beliefs, taken-for-granted values, and unconscious assumptions of their participants that were built into their teaching practices.

\section{Methodological Framework - Explanatory Case Study}

A case study is interpretive in that it uses semantic descriptions to frame descriptions of, explanations for, and meanings given to phenomena by both the researchers and the study participants and have certain features that are within the system and within the boundaries of the 
case (LeCompte \& Priessle, 1993; Stake, 1994). The case study approach was utilized because the researchers believe it is better able to help them understand the culturally responsive teaching of science teachers as they relate to culture, race, and ethnicity of "Others' (Stake, 1994). Kincheloe and McLaren (1994) argue that data from studies, including case studies, represent hidden assumptions; hence, critical analyses are needed to understand the relationship between the participants and the phenomena, which in this instance is science teaching.

Trustworthiness is an important element of qualitative research, including case studies. It is necessary that the researchers portray constructed realities in a credible way. It is understood by case researchers that they can pass along some of their own personal meanings of events and relationships; hence, efforts are made to reduce the likelihood of misinterpretation (Stake, 1994). The case study analysis is appropriate for this study because it is a way to have an intensive indepth examination of a given phenomena - the culturally responsive science teaching or the lack of it - of science teacher candidates and science teachers in teaching science to their 'Other' students.

\section{The Setting of the Study: Description of the Science Teacher Education Program}

The setting for the study described in this paper was an alternative certification program (ACP) located on a satellite campus of a traditionally White research university. The ACP is designed for students who already hold a bachelor's degree in one of the sciences but are seeking state certification. Many of the students in the ACP were teaching on a provisional (temporary) certificate; hence the courses in this program were offered in the evening with the exception of the school-based internship. The ACP program consisted of a three-semester hour methods course for science teaching and a six-semester hour school-based internship during one semester and then a three-semester hour science curriculum course and a six-semester hour school-based internship in the following semester. In the third semester, which occurred during the summer, the students in the program took a three-semester hour philosophy and leadership course, as well as a three-semester hour technology for science teaching course.

\section{Methodology}

\section{Longitudinal Qualitative Research Design}

In 2004, a group of researchers designed a two-phase longitudinal qualitative study to investigate preservice teachers' understandings about culture, race, and ethnicity and their culturally responsive science teaching. Phase A of the study concentrated on participants' ideas during the first semester in which they took science education courses. After completing a demographic questionnaire, the participants in Phase A were interviewed three times using interview protocols. The first interview focused on life experiences. Examples of descriptions that participants were asked to give in the first interview included descriptions of their culture, race, and ethnicity. For the second interview, the educational experiences of the participants were described. Questions in this interview related to the participants' understanding of the meaning of multicultural education and whether or not participants thought multicultural education should be a part of teacher preparation. In the third interview, participants were asked how prepared they believed they were to teach students who are different from them.

In Phase B of the study, the same participants were also interviewed three times. This phase focused on the second semester experiences that participants had during their school-based internships (typically referred to as student teaching) and another science education course. The first interview during this phase asked the participants to think back to their school-based 
teaching experiences. They were asked to describe the diversity of their students, describe how they saw themselves differently from their students, and describe curriculum and instructive changes they made to culturally respond to their students' needs. The second interview focused in more detail on their school-based internship. One of the key questions was, "Did your university supervisor share with you any instances in which you did not accommodate students based on their culture, ethnicity, or race?" This question was phrased in this manner to determine the participants' cultural responsiveness to their student needs. Finally, in the third interview, the participants were asked for (a) a description of those instances in which culturally responsive teaching took place, (b) a delineation of the discussions and class assignments related to culture, race, ethnicity, and science teaching, (c) if they felt prepared to teach students different from themselves, and (d) what suggestions they had to enhance their knowledge and skills to teach students who are different from them. (See the Appendix for the six interview protocols.)

\section{Description of Participants}

The two participants in this paper are a part of a larger group of students involved in this study. The pseudonyms chosen for them are Anna King and Katie Smith.

Anna King described herself as a "Caucasian" female who at the time of the study was 24 years old. She states that she went to a school

from kindergarten to second grade and lived in a White middle class neighborhood. ... went to a school with some minorities, Hispanics, and Blacks, but mostly just White. I remember the first little boy that I had a crush on was Black but I didn't really know there was a difference back then.

Anna shares that her school from third to $12^{\text {th }}$ grade was "probably $90 \%$ Black and maybe 5 to $6 \%$ White and the rest Asian. So I was in the minority." She goes on to describe her experience in the second high school she attended that was still predominantly Black in student population.

I felt more comfortable with these kids because they lived in my neighborhood. They all had homes, they all had parents who took care of them and realized that education was important. We didn't have any girls getting into problems and was all made up and if they had an earring they was trying to act all tough and so I felt so much more comfortable at that school just because, even though I was more of a minority in terms of race, I felt like I was more of a majority in terms of everything else. You know?

At the time of the study, Anna was a Master's of Education student. She was a provisionally certified chemistry teacher at a medium-sized private Christian school in the southeast. The school had about 1,900 students who are mostly White. Anna had a strong academic background in the sciences. She took advanced courses such as AP biology and AP chemistry at the high school level. Anna's high school was a large urban high school in the southeast. The high school had an enrollment of about 2,000 students with 95\% of the population being African American, $3 \%$ Caucasian, 10\% Asian, and 1\% Latino or multiracial (State Governor's Office of Student Achievement, 2007), with about $25 \%$ of the student population eligible for free and/or reduced lunches. Anna attended two universities both in the southeast, an urban university and a suburban university, both in the southeast. The first university had a total enrollment of about 6,500 , with women outnumbering men $2: 1 ; 60 \%$ of the students were Caucasian, $10 \%$ African American, $15 \%$ Asian, 3\% Hispanic, and 2\% multiracial (College Profile, 2006). The second university Anna attended had a total enrollment of about 33,000, where $85 \%$ of the university students were 
White, $6 \%$ Black, $4 \%$ Asian, and $1.3 \%$ Hispanic; $54 \%$ of undergraduates, and $60 \%$ of graduate students, were female (Internal Environment, 2000). She obtained a Bachelor of Science degree in chemistry.

Katie Smith also described herself as a "Caucasian" female who, at the time of the study, was 27 years old. Katie's academic background was strong in the sciences, as she took advanced courses such as AP biology and AP physics at the high school level and at the college level obtained a dual diploma with Bachelor of Science degrees in both biology and ecology. Katie's high school was a large suburban high school in the southeast. The high school had an enrollment of about 2,000 students, with $65 \%$ of the population being Caucasian, 10\% African American, $20 \%$ Asian, and 5\% Hispanic or multiracial with about $2 \%$ of the student population eligible for free and/or reduced lunches (State Governor's Office of Student Achievement, 2007). Katie attended the same university for her bachelor's and master's degrees. Eighty-five percent of the university students were White, 6\% Black, 4\% Asian, and 1.3\% Hispanic; $54 \%$ of undergraduates, and $60 \%$ of graduate students, were female (Internal Environment, 2000). At the time of the study, Katie was a Master's of Education student in the program. However, she was unlike most of the students in the ACP because she was not a full time teacher in a school at the beginning of the study.

Katie's teacher intern experiences were varied, as she observed two different schools and student taught in a third. The first school she observed was a large, suburban high school with about 3,450 students, 65\% being Caucasian, 15\% African American, 10\% Asian, 9\% Latino, and $1 \%$ multiracial with about $12 \%$ of the student population eligible for free and/or reduced lunches. The second school where she observed was a large middle school with about 1,700 students, $15 \%$ Caucasian, 40\% African American, 30\% Latino, 11\% Asian, and 4\% multiracial, with about $65 \%$ of the student population eligible for free and/or reduced lunches. She then student taught at a medium-sized, rural high school with about 1,400 students enrolled, $77 \%$ being Caucasian, $14 \%$ African American, 5\% Asian, and 4\% Latino, with approximately 31\% of the student population eligible for free and/or reduced lunches (State Governor's Office of Student Achievement, 2007).

\section{Data Collection Method}

Each participant completed a demographic questionnaire prior to the interviews. The questionnaire sought information about the participants' age, gender, degrees earned, degree concentration, and science, history, and humanities courses taken at the college and university levels.

According to Hays ( 2004), interviews are one of the richest sources of data in case studies; hence, semi-structured interviews employing focus questions were used in this study to uncover the "facts" about the case study and the meanings these "facts" have to the two participants in the study. As described in the research design, face-to-face interviews occurred six times with the two participants at different times in their programs.

The same White female who is one of the co-authors of this article interviewed the participants in this study. All interviews were audio taped and the tapes were professionally transcribed. Each participant received a pseudonym given to her by the interviewer. Participants reviewed the transcripts of the interviews, made any corrections, or added or changed any information given during the interviews. These member checks were done for each interview soon after the interview transcripts were available. 


\section{Subjectivity of the Researchers}

Since critical theory was used as the theoretical lens for this study, it is important to understand the cultural and racial experiences of the researchers. The first author has been conducting research in the area of multicultural science education for over 20 years. This researcher believes that research strategies should not be utilized that distort the data in order to serve the researcher's vested interests and prejudices (Patton, 1990). Hence, this researcher adopts a stance of neutrality with regard to the understanding of issues related to science teacher education research so that the complexities and multiple perspectives that emerge from the data are reported with both confirming and disconfirming evidence (Patton, 1990). Self-described as an African American female she has resided in various parts of the United States and lived in other countries, and is aware that being viewed as the 'Other' culture, race, ethnicity, and class does impact the lives of human beings involved in the schooling process, especially prospective and inservice science teachers (deMarrais \& LeCompte, 1995). Hence, she believes that it is possible to know what others experience, how Others construct their understandings, and how Others feel about their experiences. She directed the design of the longitudinal qualitative studies and assisted in the data analysis, but did not interview any of the participants in the studies. Consequently, her experiences with culturally responsive teaching and the lack of it are germane to this qualitative inquiry. When she began to teach chemistry and physical science at the university level in both Historically Black Institutions and predominantly White institutions, she did introduce the contributions of many scientists and engineers in understanding natural phenomena. In both her undergraduate and graduate level education courses, the constructs of culture, race, ethnicity, class, abilities, and sexual identity were infused. She has made instructional changes for students with vision, mental, and health disabilities and dyslexia.

The second researcher is a young self-described African American female doctoral student in science education. She has conducted various research studies that relate to culture, race, and ethnicity. For example, she has been involved in studies about the barriers to success for Black males in the sciences; other studies related to the roles of culture, race, and ethnicity in classrooms; and analyses of the levels of integration of multicultural information in science curricula. One role she played in this study was as a data analyst. She attended grade school in a small, rural school district in the southeast. Typically, about $75 \%$ of the students in this district are White, about 25\% are Black, and the percentages are minimal for other races. She received a B.S. in Science Teaching: Biological Sciences from a medium-sized, predominately White institution in the southeast and earned a M.Ed. in Science Education at a large, predominately White institution in the southeast. She has taught a variety of biology, physical science, health, and anatomy and physiology classes (among other things) at the middle school, high school, and college levels in both rural and urban schools. Additionally, she has taught several different elementary and secondary science teacher preparation courses at the university level and served as a supervisor for elementary and secondary student teachers. In all of these situations, she detected the influences of her own culture, race, and ethnicity as well as the cultures, races, and ethnicities of her students on the various aspects of their lives. There were situations where this researcher made instructional changes for her students. These changes were most commonly for learning, physical, and behavioral disabilities. For example, students were given extra time for tests and other assignments, allowed to take tests in other rooms, given special seating privileges, granted special "cool down" courtesies, or given specifically modified assignments. However, this researcher also always made an effort to integrate various aspects of the students' races, cultures, and ethnicities into the lessons and allowed alternative ways for the students to meet the objectives. Furthermore, this researcher realized that instructional practices made outside of the classroom could have a positive effect inside the classroom. There were some students who 
needed mentor/mentee relationships or support in their other activities (such as athletics and arts) in order to be more successful in the classroom. She also required the prospective teachers whom she taught and supervised to make an effort to integrate the races, cultures, and ethnicities of their students into their lesson plans and activities.

The third author takes the stance that for researchers, "a degree of self-location is possible and valuable, particularly when it points beyond the individual toward ongoing webs of relationships" (Clifford, 1997, p.12). As a self-described African American male science teacher educator, he believes he must consistently filter and articulate his thoughts and feelings about this research study through the fore-grounded lenses of culture, race and ethnicity. As an African American male, he experiences both beneficial and deleterious outcomes of race and ethnicity almost daily as they relate to his work with inservice and preservice teachers. The majority of these teachers are White, whereas significant numbers of their students are African American and Latino. Thus, there may be instances where certain aspects of teacher-student and student-student interactions may cause educators to talk with him differently than other researchers, as educator respondents might view him as an insider when in reality he is more of an outsider (Jarvie, 1969). Indeed, he may even interpret the educators' responses markedly different than researchers of other races and ethnicities. Finally, most of the participants in this study were females and he was the only male researcher. Although this demographic variable was not explicitly addressed in the research questions, the possible confluence of gender with the studied variables must be taken into account as the results of this study are interpreted. Hence, this researcher brings to the research study a different lens due to his experiences.

At the time of this study, the fourth author was a 29 year-old self-described "Caucasian" female. She is a doctoral student at a large university in the southeast. After teaching for three years in a large urban high school, she returned to school to obtain her advanced degrees. She enrolled in the same university and department where she had obtained her undergraduate degree a few years before. Her research experiences are varied, but this was her first experience researching issues directly related to race, culture, and ethnicity. Over the course of this project, the author interviewed several female participants with whom she had not met or had contact.

During her tenure as a teacher, she made instructional changes for her students by attempting to meet the needs of students with special needs (students who were illiterate or those who had low reading achievement, vision and hearing disabilities, emotional and behavioral disabilities, medical concerns, and those who required speech and language assistance), by using preferential seating, modified and un-timed testing, oral testing, retaking or recompleting of assignments and assessments, and alternative assignments.Additionally, she made regular instructional changes for English-language learners and for students who had special home circumstances: divorced, deceased, single or foster parents, as well as living with other relatives. The changes included alternative assignments and allowing late work. The researcher did culturally respond in her teaching specifically in terms of race, culture, or ethnicity by incorporating the study of scientists from a variety of races (and both genders) in her class to highlight scientists who were not White males, celebrating diversity by having students bring in foods they felt were indicative of their cultures, and understanding her students' popular culture by keeping up with magazines of interest, popular music, and special greetings, and handshakes. She allowed her students to write songs, to perform raps about important concepts, to make collages, and to draw analogies that made sense to them since she believes that keeping up with students' interests was the key in establishing rapport and respect among and with her students.

It was essential to have so many researchers involved in this study. One of the researchers should be of the same culture and race of the participants to assist the other researchers in making meanings of participants' words and help the participants feel like she is familiar with their life 
experiences. This approach brought more trustworthiness to the study. However, it was also vital to have researchers different from the participants in culture and race because they better understand how culture, race, and ethnicity influence what happens in science classrooms. They provided the insight into the kinds of interview questions asked and brought different lens to the interpretation of the data. The use of several different researchers is one way of triangulating data and provides multiple perceptions to clarify meaning (Flick, 1992).

\section{Data Analysis}

The intention of a case study is to answer questions rather than produce a complete picture of the case (Hays, 2004). Using the four research questions as a guide, the investigators dissembled the interview data, looked for relationships, and reassembled the data to tell the participants' stories and answer the research questions. Data from this explanatory case were analyzed using the method of analytic induction (Frankfort-Nachmias \& Nachmias, 1996).

Three of the four researchers had access to the real names of the participants, the first author chose not to have access to the participants' names because she could either be their advisor or would teach them in the future. However, all researchers read the interviews, reviewed the data independently, and questioned each other in meetings about the interpretation of the data, utilizing inductive analysis. Patterns emerged from the interview data about the understandings and the culturally responsive teaching of the participants (Patton, 1990).

To enhance trustworthiness of this study, the researchers employed a form of triangulation multiple analysts (a group of four) to review the findings of the study (Patton, 1990). Also, to establish credibility of the findings, the researchers shared personal and professional information that may have affected the data collection, analysis, and interpretation (Patton, 1990). Finally, the interviewer, who is one of the researchers of the study, did member checks to ensure the creditability of the study (Janesick, 1994; Lincoln \& Denzin, 1994). The researchers met as a group during the study to discuss theoretical frameworks being used, concepts such as culture, race, and ethnicity, and how the participants' understandings differed from theirs, wrote notes about the process of conducting this longitudinal case study, and discussed follow-up questions to be asked by the interviewer based on previous interviews.

\section{Findings}

\section{The Case of Anna King}

Knowing how Anna defines accommodation, culture, race, and ethnicity is helpful in understanding her beliefs about accommodations. Anna describes an accommodation as "how you treat someone." She defines culture as:

How you were raised. And that would include your parents' roles in the family when you were a child. How life is kind of structured. How you handled doing homework or how you... whether or not you were allowed to watch television as much or, you know, only at times. How you dealt with your extended family or whether your two parents worked. You know I think all those things factor into culture. It's kind of how you live your life... I mean in all those different ways.

Anna tells us that "race is more about just like your genes." According to Anna, 
ethnicity mostly has to do with the country you come from. And mostly has to do with which country you are.... or... the country's culture you were raised in. Because you could be a first generation and you just moved here when you were 35 or something and ethnicity would definitely be from the other country. You could have moved here and had a child and so that child could still be raised mostly... you could have raised them mostly as American and then that kid would probably be more American. So you have a lot of ethnicity that you are raised with.

In self-reflecting, Anna shares her "clarified" ideas of ethnicity and race by stating that "ethnicity is when you have been raised in a certain culture. And so race would mean more of what country your ancestors come from."

Importance of culturally responsive teaching of the 'Other'. Since Anna was teaching on a provisional certificate throughout the study, the importance she places on culturally responsive teaching was gauged in terms of how it was demonstrated in her teaching. When Anna is asked if she accommodates students from different races to determine if she practices culturally responsive teaching, she answers "no". Later, she shares "I treat them the same way and I think all of them have an equal chance to learn." She believes that when the learning of her students is hindered, "it is mostly a mental thing... a mental thing inside their head." Furthermore, "it has nothing to do with their race."

Anna states that she does respond to her students from different cultures and ethnicities. When asked to explain, she tells us

... because I think that ethnicity and the culture have a lot more to do with their achievement in the classroom than race does. To me, race is just the color of your skin and I don't think affects how your brain works or your behavior in class or how well you can understand me. If you are from a different culture and you are programmed to behave a certain way... or you are programmed to learn a certain way, that's a whole different thing. You know if you are from a different country, you have a different ethnicity, ah... then there is usually a language barrier too and there is also usually behavior and learning differences also. You know? Because of the way you grew up... maybe you was $[s i c]$ taught a different way at the very beginning. And so I think there is some accommodation to be made there because that does affect your ability and the way you behave in class.

In a later interview, Anna is asked if she thinks a student's culture, race, or ethnicity influences the student's ability to understand science concepts. She answers "no" in response to all three. However, she does explain that "if culturally their parents have discouraged them from certain areas of science," an influence on the ability to learn science concepts might exist. This could possibly cause students to "have a barrier put up."

There are other times during Anna's interviews that she mentions her beliefs about accommodations. For example, when describing multicultural education, she posits that teachers should:

make sure that you understand that your kids are all coming from different places whether its different home lives or different churches or different types of parents.... Everybody is an individual. Everybody has got special characteristics and special situations and I think treating your students as individuals is $[s i c]$ the strongest thing you can do. 
Anna also mentions that with multicultural science education, teachers should "include scientists from different cultures." She then elaborates on three levels of multicultural education. "The first level would be just inclusion, like on special holidays." Anna mentions that she had recently done an "inclusion" lesson on George Washington Carver. "The second level would be to integrate it into your lesson when you talk about people from different cultures in lots of different areas without having to be asked to do it." Anna shares that "the third level makes me more angry $[\mathrm{sic}]$. The third level is where you're actually an example for the kids... like a social activist... like you are being a leader."

Although Anna implies that she does not agree with some of these principles of multicultural education; she does state that "this might seem like a really small thing, but I think it makes a difference." Anna believes that when a teacher shows students that they respect "somebody of a different race or culture" and "value someone through their works and everything," it "makes a huge impact." She adds "if you, in your personal life, were really interested in different cultures..., you need to tell that to your kids." She also thinks that teachers should share with their students if they take "classes at night on different kinds of stances" or if they "are involved in a community center for Hispanic students that needed help with their school work." She contends "that it sets a better example [than] when you are just talking about it." Anna asserts "there is no way you can teach that kind of thing if you can't live it or feel it yourself." Anna also believes that it is important to add things, such as "guest speakers who are minorities," to the curriculum "when it's comfortable." She articulates that this could "make a big difference... [because] minorities are still underrepresented." She gives further details:

that kind of makes it even harder for students that are growing up that are in the minority to feel like they can achieve higher... goals than maybe their parents or for them even. That's showing them that people can achieve these certain things. And it really does sort of help.

Prior experiences with culturally responsive teaching of the 'Other'. Anna could not recall ever noticing other teachers accommodating students from different races, cultures, or ethnicities. However, she did notice that with "acceptance to college and scholarships and stuff a lot of minorities got social advantages, but that was not really teachers doing it." In addition, she shares those Black students who applied to her undergraduate institute "got extra points" for their college applications. Anna expresses that she does not understand why "they get more points than I do just because of their skin color." She expounds:

I don't think they had any disadvantage, you know, they went to a school where they were the majority and I mean their parents were just as wealthy, if not more than mine and they had the same exact educational experience, you know, but they had darker skin than I did. And I had White kids that went to my earlier school that were completely disadvantaged because their parents were poor. They didn't even live in a real house. They didn't have enough money to buy food and they didn't get those extra points. They had no chance to get into a school like that.... It just seems so unfair to me because I think it should be determined more on culture than it should be on race.... That frustrates me.

Anna also mentions a case study that she read for and discussed in one of her teacher preparation courses. She depicts a story of a White male teacher who attempts to culturally respond to his "majority Hispanic" class. 
He comes up with this idea for them to design cars with the little letters.... So he has them design the cars and this has to do with Chemistry and Physics or something like that.... I think he shared this idea with one of his peers at this school that he was teaching at and she was Hispanic and she was just floored that he would do this and totally appalled and offended.

Anna describes this effort as "hokey" and affirms that it is not something that she thinks she would do.

Participant's culturally responsive teaching of the 'Other'. When Anna is asked during the last phase of the study if she responds to the cultures of her students, she answers:

It depends what you mean by accommodate. But I would say maybe a little bit. And accommodate would not be curriculum, it' $\mathrm{d}$ be accommodate in the way that I deal with them or the way that I behave.

When asked for an example, she shares:

I have a student who does not have a father at home and he likes a lot of attention and so he is rather rambunctious in class. But I understand that's where it comes from and that's part of where he is getting all this energy and need for extra attention. Think I can just give him the extra attention but not feel bad that I am neglecting the other kids. You know what I am saying? I just make sure I stand close to him during class to try to keep a tight rein on him. Because I know he needs that extra enforcement. And I would say not having a father at home would definitely be a cultural difference. Because you grow up very differently. He is also one of my Black students too. But I think not having a father at home is what's causing the difference.

Anna also shares:

sometimes your culture can affect how involved your parents are in your education. And so I think I do accommodate to some extent in terms of when I get the parent involved in a problem at school. So if they are in a culture where they are supposed to handle things independently, then you want to give them a little bit more time to deal with that problem whether it's a grade or behavior problem.

She continues to believe that race is not "a barrier at all on your ability in the classroom or how you are expected to behave or things like that." For this reason, she still does not make accommodations for the race of her students.

During the later phase of the study, Anna does state that she makes accommodations based on the ethnicity of students. She elaborates:

for example the girl that I spoke about last interview. She is Asian, and even though she is not in the honors program anymore she still struggles a lot with the English language and so even during a test.... She is a really bright student and has passed all the tests.... An " $\mathrm{A}$ " on everything. I mean she works real hard and she comes to me and asks me what a word means.... I know it's not because she didn't study her vocabulary because she honestly doesn't understand what I mean. And sometimes I will give her definitions of words and I will look at the other kids... like... you know... I might have to keep a special eye on her while I'm talking in class to make 
sure she follows what I am saying. Because I know if she doesn't, it's because of the language.

In discussing accommodations based on ethnicity, Anna once again mentions level of parent involvement. She allows a parent who works as an engineer in the school multiple and lengthy conferences "because I know him and I know this is crucial to how his family works.

Anna does not think that she has made any changes to curriculum, instructional strategies, or assessment and evaluation as accommodations for students' culture, race, or ethnicity. She states that she has made instructional changes, but does not think they were made "specifically for those reasons."

Restructuring science teacher preparation programs. Anna does not believe there was enough time during her ACP to include all of the needed experiences. She would love to have had "time to go to see everybody's teachers in different school settings." She makes the following suggestions:

I feel like even something simple like have the students go as a group or maybe miss a class... here and there and use that time to go... I am thinking of like tutor with some kids who are maybe in another socio-economic level or even in a different race or ethnicity just to be able to get some one on one.

Anna believes that "to see real teaching environments and see how they are different" in addition to "being able to see what different teachers are dealing with and being able to add on top of that how you handle different things" would be very helpful. She considers exposure to be the key and suggests that opportunities to "observe lots of different kinds of classrooms and interact with different kinds of kids" be available. Anna believes that it is also important to discuss these experiences. She suggests that the visits be written about and talked about in class "because just having them do it isn't as helpful as making sure they actually have thought about it in that specific area." Additionally, Anna points out that

violence, drugs, and things like that... would be harder for me to deal with, of course, than like a racial difference. You know? So I think learning how to deal with things like that will probably be really helpful. Not just focusing on the race difference.

\section{The Case of Katie Smith}

Just like with Anna, it is helpful to know Katie's descriptions of accommodation, culture, race, and ethnicity. Katie thinks of accommodating "as trying to make them feel more like a part of the whole group and not feel like an outsider because they are different." She defines culture as "like how a person... like their environment that they grew up in, their different traditions and... their language... type of things that they eat... anything that is part of their environment." She defines race as "different skin color." "Like where they are from, their background, as far as like what country they're from" is her description of ethnicity.

Importance of culturally responsive teaching of the 'Other'. When Katie is asked if she plans to be responsive to her students from different cultures, she answers:

I think yes. I would accommodate in some ways, but I think there is a lot of things that I don't know how I would do it. I don't, and I don't think a lot of people - or at least that I have talked to - know how to do it. 
Katie was asked why she wanted to be able to respond to her students' cultures. She responds:

Because I think, it's not only important for the students of a different race or ethnicity to feel like they understand more in that they are part of the class, but I think it is also important for the other students to understand each other... their other peers' culture and their points of view and their ways of thinking.

Katie confesses her thinking pattern prior to being exposed to concepts of multicultural education:

I guess I tended to think, oh, everyone is like me and they think the same way. And kind of had the same thinking pattern that I do and it helped me to see that not everyone is like that. And so you have to, I guess, do certain things that would maybe interest people with different cultures and races or even different thinking styles to get them interested in what you are teaching.

Katie also plans to respond to the needs of her students from different races and ethnicities. To both questions she replies, "I think that's the same." She plans to respond to race and ethnicity the same way that she plans to respond to culture - by emphasizing information that relates to the races and ethnicities of her students. Katie reminds us that she is unsure of how specifically to culturally respond in her teaching.

Prior experiences with culturally responsive teaching of the 'Other'. Katie has witnessed teachers accommodating for the race, culture, or ethnicity of students. Initially, Katie tells us that she does not know if she has ever really noticed any accommodations made by teachers that were based on culture. She continues by stating:

I was usually in the honor classes and so most of the people in there were, you know, if they were from another country they could speak English fairly well and, you know, kind of tested into those classes. So they knew the language fairly well.

When asked if she had experiences in her education with teachers accommodating students from different races, she responded "probably." She elaborates that she did not know if she would have even "noticed something like that." If anything, "it would have been my own... that was what the teacher was teaching today or that's just how it is." At one point, she mentions the same case study that Anna described (about a teacher making accommodations for Latino students). Katie shares the following story in response to being asked about experiencing teachers accommodating for ethnicity:

Like the teacher that I was with this past week, she had a student who was Asian and he didn't speak English very well. So she would print out the notes for him and leave blanks so he would have to listen so he could fill in the blanks. But he didn't have to write everything out like everyone else because he was just too slow and he didn't understand everything. And so she did that to make it easier for him. But I think that was.... I guess that is accommodating for ethnicity, but I don't know if she looked at it like that or if she looked at it as he doesn't know English very well and so this is what he needs. 
When Katie is asked about curriculum changes she has seen made by other teachers due to students' cultures, races and ethnicities she answered, "I don't know if it is based on like... I don't think it's based on culture or race. I think it's based more on the academic level... like honors versus tech classes." More specifically, she has witnessed:

just like more repetition for the lower level classes. More review... And one teacher, she does flash cards every day to review key stuff that they have done before just to kind of keep it fresh in their minds because she knows that they are not going ... most likely they are not going to do it on their own. Whereas her honor's kids are gonna go home and they are going to study and that's one big difference.... She does a lot of matching.... She does a lot of visual stuff where it's using their hands.

Katie also tells of seeing a teacher give a copy of the notes or fill-in-the-blank notes to students who were poor readers or writers whereas, other students were responsible for writing all of their own notes.

Katie also recalls modifications in assessment and evaluation made by teachers based on culture, race, and ethnicity of students. She informs us about her mentor teacher:

She uses more, I think in her lower level classes, she uses more like participation. She will do that more. So if they know that... it's being graded, then they are more likely to do it.... As far as like tests go, if there is matching and there's a lot of words, she will break it down into [smaller groups]. Say you had twenty words, then she'll split it up in four groups of five so they don't have so many words to choose from. She does more projects like building models in that class.

Participant's culturally responsive teaching of the 'Other'. When Katie is asked about her accommodation with students who are different from her, she shares the following:

I guess the main one would be like doing more hands-on type activities that don't necessarily you don't.... even if you don't know the language very well, if you see it and you do it you are going to grasp the concept without having to, I guess, read a lot about it.

Katie believes that her changes to instructive strategies are "more based on level of the class than their culture or their race." However, she does reveal that she uses a lot of flash cards and that the flash cards are "really making a difference with them." She also shares, "if I think they struggle, then I try to match them with a lab partner that does well in the class to see if that helps them to do better." Katie reveals that she does "not really" make changes in assessment or evaluation to respond to students' cultures, races, or ethnicities. Furthermore, she cannot think of any curriculum changes she made to respond to her students' cultures, races, or ethnicities.

Restructuring science teacher preparation programs. Katie is asked if she thinks her science teacher preparation program has prepared her to teach students who are different from her. She responds:

I think it is preparing me to I guess think more about those students, where as before, I probably wouldn't have thought any differently. But I don't know if it has given me... I don't know if I have any strategies that I could use that would help me to teach them better or to involve them more. 
She also shares "I think they did a good job of having us in different schools with different types of settings... where you can see different demographics of students."

Katie reveals one of the shortcomings of her program by explaining that many of the mentor teachers never thought about the roles of culture, race, and ethnicity in their classrooms. When she would ask them about these topics they would admit that they had "never really thought about" it and that they "teach everyone kind of the same way."

Katie makes several recommendations for improving the program. One recommendation is to be exposed to strategies for accommodating students' cultures, races, and ethnicities. She suggests "showing maybe videos of teachers that actually accommodate... that... are accommodating for them and showing that to class and pointing out... what's going on and what that teacher is doing to help the different students in the class." She expounds:

I think just to be able to see someone do it would be helpful.... So having a visual there instead of just talking about it or giving suggestions... actually seeing someone do it.... Just talking about it more too because I think we spent... just one day talking about it. I don't feel like we... really got a whole lot out of it.

Another recommendation made by Katie involves time spent in the schools. She states:

Probably if maybe there was like less schools so that you could spend more time at the different schools. So that you could maybe get to know the teachers and the students better and how they interact with each other.

\section{Discussion}

The researchers in this study employed a socio-cultural lens to analyze science teacher candidates' understandings of 'Other' students' cultures, races, and ethnicities and the ways they culturally responded to the 'Other' students' needs in their science classrooms. The use of critical theory allows the researchers to conduct a social/cultural criticism of the findings of this study because the researchers understand that the participants' language is not neutral and objective, but indicates how the participants construct their teaching world (Kincheloe \& McLaren, 2005). Since teachers are powerful beings in a classroom, the participants' discourse provides insights into the participants' understandings about what instructional methods should be utilized in what context, what curriculum materials are appropriate, and who should be given the opportunity to learn quality science. Hence, it is essential that the researchers interpret the words of the participants in a critical manner.

\section{The Importance of Culture, Ethnicity, and Race Varies}

According to the two participants, culture and ethnicity might be important sometimes; race is very unimportant. Anna wanted her students to have an "equal chance to learn," but thought that culture and ethnicity were more influential in the students' science learning. Neither Anna nor Katie believe that the race of a student was an important characteristic in learning science because race was more about your genes or skin color. Anna believes that if a student is not learning, then it is a mental thing. In other words, she would probably disagree with the thinking that there might be a relationship between how students view themselves as racial beings and learning science. For her, culture and ethnicity affect students' behaviors and their ability to understand science. However, the concept of individualism drives Anna's interactions with her 'Other' students. Individualism and meritocracy as described by Solomon, Portelli, Daniel, and 
Campbell (2005) help her to defend her notions that the 'Other' students just need to work hard for them to be successful because they have access to opportunities. As a teacher, she behaves differently with individual students - not understanding that the 'Other' students with similar microcultures might require the same kind of behavior from her.

\section{They Heard, But Did Not See}

Anna could not recall one incident in which she saw other teachers responding culturally to their 'Other' students. She described her one example as "hokey" - a case study about Latino students that she read in a teacher education class. Katie does admit she probably did not have the lens to notice culturally responsive teaching. As mentioned earlier, Katie thought that everyone was like her until she was exposed to the concepts of multicultural education. However, both Anna and Katie saw teachers with the 'Other' students, but did not see any of these teachers responding culturally to their 'Other' students. They mostly saw teachers seemingly teaching students the same way. Both want to view and understand culturally responsive teaching in science classrooms. They want visual images. Modeling the practice of culturally responsive teaching in both courses in science teacher education programs and schools is essential if teachers will have a vision of what this kind of teaching is and is not (Villegas \& Lucas, 2002).

\section{The Participants are Unsure about Several Issues}

Anna believed that facileness with the English language, which may be due to ethnicity, impacted learning. However, Anna later stated that a student's culture, race, and ethnicity do not influence the student's capability to learn science. However, she reported that she does and plans to continue to treat all of her students the same. She seems to be unsure about this stance because she does believe that, "culturally", parents can discourage their children from certain areas of science, which might impact the students' willingness to understand science concepts. She believes that parents share more of the responsibility for their children's learning than the teacher.

Anna is able to identify three levels of integration of multicultural education into science teaching: inclusion by way of special holidays, inclusion that is teacher motivated, and social activism, which she abhors. She thinks multicultural education is a "small thing," but believes that respect is very important to students. She did not understand that multicultural educators do advocate for respect; along with respect goes the opportunity to experience quality science learning and teaching. One of the goals of education, especially science education, is that the learners are able to act upon their knowledge and skills to change their world (Atwater \& Riley, 1993). People who are marginalized, oppressed, or disenfranchised need quality knowledge and skills to fight their marginalization, oppression, and disenfranchisement (Bybee, McCrae, \& Laurie, 2009; Delpit, 2006; Freire, 2005; Garcia, 1995; Giroux, 1992).

Even though these two participants have experienced the same teacher education program, they have differences in their ideas about privileging of the 'Other' students. Anna believes that privilege is only based on class; she believes that Black students from the same economically advantaged homes like Whites should not receive any acknowledgment of their historical and cultural experiences of oppression. She is unaware that students from similar economic backgrounds, but from different races, can and do experience oppression and discrimination.

\section{They Did for Some, but Not for Others - Why?}

During her science teaching experience, Anna did respond to the needs of one Asian student who she believed was a hard worker and "bright" by giving her definitions of words due to the 
student's limited command of the English language. She also shares a story about a father's interest in his daughter. Lengthy conferences are given to the father because Anna has embraced the western ideas of parental involvement in their child's learning. She believes that parents share more of the responsibility for their children's learning than the teacher. She does not know that some parents from other cultures believe that school personnel are experts in teaching and learning and that parents should not interfere (Hidalgo, Siu, \& Epstein, 2004; Hurtado, 1995; Jeynes, 2009; Spring, 2004; Wei-Cheng, 1997).

On the other hand, Katie responds to her students based on the academic level of the classes she is teaching. She makes no connection to the kinds of students found in her tech classes versus honor classes (In the tracking system in U.S. schools, students are enrolled into a level of a course based on their perceived ability to handle the course materials. Tech courses are viewed as lower level courses for students who cannot handle difficult, rigorous work. She has not noticed that her tech classes are composed mostly of Black students and her honor classes consist of White students. It appears that the two participants did not acknowledge, neither do they understand, that there are relationships among and within race, class, and quality science teaching).

\section{Implications for Teacher Education and Research}

\section{Implications for Teacher Education}

According to Hollins and Guzman (2005), "critics from both inside and outside teacher education have suggested that traditional... teacher education has not done an adequate job preparing teachers to teach diverse populations" (p. 478). The findings of this qualitative study suggest that science teacher candidates, like candidates in other disciplines, continue to struggle with their ideas about culture, race, and ethnicity and their commitment and abilities to teach in a culturally responsive manner. When science teacher preparation programs do not infuse multicultural education, teacher candidates have little opportunity to develop their knowledge and skills to respond to students' cultures, races, and ethnicities so that their future students have an equitable opportunity to learn quality science (Gay \& Howard, 2000). Both Anna and Katie desire opportunities to see students of different races, ethnicities, and social classes being taught successfully. They want more opportunities to work with mentor teachers who are successful in teaching all students. However, preservice teachers such as Anna and Katie also need opportunities to reflect upon their constructs of race, ethnicity, and culture and their interrelationships with teaching. Milner (2003) advocates that they should spend time uncovering inconspicuous beliefs, perceptions, and experiences, specifically where race is concerned. He advances the concept of race reflection in cultural contexts.

We believe that mentor teachers in the Alternative Certification Program that was the focus of this study need the values, beliefs, and successful teaching experiences so that they can assist their practicum students and student teachers in working with the 'Other' students. In other words, prospective science teachers need to experience teachers accommodating students with their curricular, instructional, and evaluation practices.

There are a few teacher educators who are committed to preparing teachers to teach the 'Other' students (Corti, 2002; Darling-Hammond, 2002, 2006; Delpit, 1995; Lowenstein, 2009; Ruiz, 2002; Traudt, 2002). Nonetheless, more science teacher educators must be committed to restructuring their science teacher education programs so that their prospective teachers will have successful experiences teaching the 'Other' students. Otherwise, we will continue to have students like Anna and Katie in our programs that at the end of their programs are not willing (or 
willing on a very limited basis) to consider the 'Otherness' - culture, race, and ethnicity- as they relate to curricular, instructional, assessment, and evaluation issues in science teaching.

\section{Implication for Future Research Studies}

A team of scholars of color, along with a White scholar, can be revisionist because they offer new insights, informed alternatives, and potentially unsettling ways of thinking about preservice teacher education and offer novel ways of investigating the practices of preservice and inservice teachers. As denoted by this research study and numerous propositions that surround the preparation of teachers for the 'Other' students, more in-depth investigations are needed to ascertain how teacher preparation programs shape science teachers' knowledge and practices in both the United States and other countries. More national and international longitudinal studies are essential for this kind of investigation. But to understand this shaping, we need to better understand the nature and quality of science teacher education curricula, instructional practices, and organizational arrangements, especially in preparing teachers to teach 'Other' students in different kinds of settings. Additional studies are needed to examine the connection between teacher education and elementary through high science learning and dispositions toward science, especially for students who do not belong to the dominant culture(s) and learners who do not speak the national language(s) at home .

Finally, this study has led us to pose the following questions regarding the need to prepare science teachers who can be successful in teaching 'Other' students:

- What experiences are necessary for teacher candidates, whose lives have been very different from the 'Other' students, to be committed to and have the knowledge and skills to teach these students?

- Do we need different kinds of psychological and social foundation courses than the ones which are currently being offered in teacher education programs?

- Do we need additional general education requirements in order for teacher candidates to be successful in teaching the 'Other' students?

- Is it essential that science teacher education programs have science teacher educators who have been successful teaching science to the 'Other' students and also have the commitment to change science teacher education programs so their graduates, at minimum, can be successful in teaching all of the 'Other' students in their country?

As science teacher educators and researchers continue to earnestly struggle with preparing science teachers who can be effective in diverse classrooms, we offer this study and the aforementioned questions as foundational information and points of departure for future explorations. The students in our classrooms deserve nothing less from us.

\section{Acknowledgement}

The authors thank Professor JoBeth Allen who directed the College of Education Faculty Writing Retreat sponsored by the Office of Research at the University of Georgia for her helpful comments in revising this manuscript. 


\section{References}

Abell, S. K. (2007). Research on science teacher knowledge. In S. K Abell \& N. G. Lederman (Eds.), Handbook of research on science education (pp. 1105-1149). Mahwah, NJ: Lawrence Erlbaum Associates.

Alba, A. (1990). Ethnic identity: The transformation of White America. New Haven, CT: Yale University Press.

Atwater, M. M., \& Riley, J. P. (1993). Multicultural science education: Perspective, definitions, and research agenda. Science Education, 77(6), 661-668.

Atwater, M. M., \& Crockett, D. (2003). A world view of preservice teachers:Through the eyes of ethnicity and culture. In S. M. Hines (Ed.), Multicultural science education: Theory, practice, and promise (pp. 55-86). New York: Peter Lang.

Aikenhead, G. S., \& Otsujui, H. (2000). Japanese and Canadian science teachers' views on science and culture. Journal of Science Teacher Education, 11, 277-299.

Banks, J. A. (1973). Teaching ethnic studies: Concepts and strategies ( $43^{\text {rd }}$ yearbook). Washington, DC: National Council of Social Studies.

Banks, J. A., \& Banks, C. A. (1989). Multicultural education: Issues and perspectives. Boston: Allyn \& Bacon.

Barton, A. C. (2007). Science learning in urban settings. In S. K. Abell \& N. G. Lederman (Eds.), Handbook of research on science education (pp. 319-344). Mahwah, NJ: Lawrence Erlbaum Associates.

Bonilla-Silva, E. (2006). Racism with racists: Color-blind racism and the persistence of racial equality in the United States. Lanham, MD: Rowan and Littlefield Publishers.

Brown, A. H. (1998). Equity and empowerment in the mathematics classroom. Curriculum and Teaching, 13(2), 45-57.

Bryan, L. A., \& Atwater, M. M. (2002). Teacher beliefs and cultural models: A challenge for science teacher preparation programs. Science Education, 86(6), 821-839.

Brown, E. L. (2004). What precipitates change in cultural diversity awareness during a multicultural course? Journal of Teacher Education, 55 (4), 325-340

Brown, A. H., Cervero, R. M., and Johnson-Bailey, J. (2000). Making the invisible visible: Race, gender, and teaching in adult education. Adult Education Quarterly, 50(4), 273-288.

Bybee, R., McCrae, B., \& Laurie, R. (2009). PISA 2006: An assessment of scientific literacy. Journal of Research in Science Teaching, 46(8), 865-883.

Chenoweth, K. (2007). "It's being done" academic success in unexpected schools. Cambridge, MA: Harvard Education Press.

Clifford, J. (1997). Routes: Travel and translation in the late twentieth century. Cambridge, MA: Harvard University Press.

Cochran-Smith, M., Davis, D., \& Fries, M. K. (2004). Multicultural teacher education: Research, practice and policy. In J. A. Banks (Ed.), Handbook of research on multicultural education (931-978). San Francisco: Jossey-Bass.

Cochran-Smith, M., \& Zeichner, K. (Eds.) (2005). Studying teacher education: The report of the AERA panel on research and teacher education. Mahwah, NJ: Lawrence Erlbaum Associates.

Cohen, E. G. (2006). Equitable classrooms in a changing society. In M. T. Hallinan (Ed.), Handbook of the sociology of education (pp. 265-284). New York: Springer.

$\begin{array}{llllll}\text { College } & \text { Profile. } & \text { (2006). Retrieved } & \text { March 20, }\end{array}$ http://college.sparknotes.com/school/index.epl?inun_id=6261\#studemo.

Corti, C. (2002). Finding myself in my students: A step toward transforming social dynamics in the classroom. In L. Darling-Hammond, J. French, \& S. P. Garcia-Lopez (Eds.), Learning to teach for social justice (pp. 52-58). New York: Teachers College Press.

Cronin-Jones, L. L. (1991). Science teachers' beliefs and their influence on curricular implementations: Two case studies. Journal of Research in Science Teaching, 28, 235-250. 
Cross, W. E., Jr. (1971). The Negro-to-Black conversion experience: Toward a psychology of Black liberation. Black World, 20(9), 13-27.

Darling-Hammond, L. (2000). Teacher quality and student achievement: A review of state policy evidence. Education Policy Archives, 8(1), Retrieved March 26, 2007, from http://epaa.asu.edu/epaa/v8n1/.

Darling-Hammond, L. (2002). Educating a profession for equitable practice. In L. Darling-Hammond, J. French, \& S. P. Garcia-Lopez (Eds.), Learning to teach for social justice (pp. 201-212). New York: Teachers College Press.

Darling-Hammond, L. (2006). Powerful teacher education: Lessons from exemplary programs. San Francisco: Jossey-Bass.

Darling-Hammond, L. \& Sclan, E. M. (1996). Who teaches and why: Dilemmas of building a profession for twenty-first century schools. In J. Sikula (Ed.), Handbook of research on teacher education (pp. 67-101). New York: Macmillan.

Darling-Hammond, L., \& Snyder, J. (1998). Authentic assessment of teaching context. Teaching and Teacher Education, 16, 523-545.

Delpit, L. (1995). Other people's children: Cultural conflicts in the classroom. New York: The New Press.

Delpit, L. (2006). Lessons from teachers. Journal of Teacher Education, 57(3), 220-231.

deMarrais, K. B., \& LeCompte, M. D. (1995). The way schools work: A sociological analysis of education. White Plains, NY: Longman.

Flick, U. (1992). Triangulation revisited: Strategy of validation or alternative? Journal for the Theory of Social Behavior, 22, 175-198.

Frankfort-Nachmias, C., \& Nachmias, D. (1996). Research methods in the social sciences. New York: St Martin's Press.

Freire, P. (2005). Teachers as cultural workers: Letters to those who dare to teach (F. Macedo, D. Koike, \& A. Oliveira, Trans.). Boulder, CO: Westview Press.

Garcia, E. E. (1995). Preparing instructional professions for linguistically and culturally diverse students. In J. A. Banks \& C. A. Banks (Eds.), Handbook of research on multicultural education (p. 372-411). San Francisco: Jossey-Bass.

Gay, G. (2000). Culturally responsive teaching: Theory, research, and practice. New York: Teachers College Press.

Gay, G. (2002). Preparing for cultural responsive teaching. Journal of Teacher Education, 53, 106116.

Gay, G., \& Howard, T. C. (2000). Multicultural teacher education for the $21^{\text {st }}$ century. Teacher Education, 36(1), 1-16.

Giroux, H. A. (1992). Border crossings: Cultural workers and the politics of education. New York: Routledge.

Grant, C. \& Ladson-Billings, G. (1997). Dictionary of multicultural education. Phoenix, AZ: Oxyrx Press.

Grant, C., \& Secada, W. (1990). Preparing teachers for diversity. In W. R. Houston, M. Haberman \& J. Sikula (Eds.), Handbook of research on teacher education (pp. 104-114). New York: Macmillan.

Grant, C. \& Sleeter, C. (1997). Turning on learning: Five approaches for multicultural teaching plans for race, class, gender, and disability. Upper Saddle River, NJ: Merrill.

Haberman, M. (1996). Selecting and preparing culturally competent teachers for urban schools. In J. Sikula, T. Buttery, \& E. Guyton (Eds.), Handbook of research on teacher education (pp. 747760). New York: Macmillan.

Hall, S. (1992). Race, culture and communications: Looking backward and forward at cultural studies. Rethinking Marxism, 5(1), 10-18. 
Hamilton, M. L. (1996). Tacit messages: Teachers' cultural models of the classroom. In F. A. Rios (Ed.), Teacher thinking in cultural contexts (pp. 185-209). Albany, New York: State University of New York Press.

Hardiman, R. (2003). White racial development in the United States. In P. E. Saett \& D. R. Koslow (Eds.), Race, ethnicity and self: Identity in multicultural perspective (pp. 117-136). Washington, DC: National MultiCultural Institute.

Hays, P. A. (2004). Case study research. In K. deMarrais \& S. D. Lappan (Eds.), Foundations for research: Methods of inquiry in education and the social sciences (pp. 217-234). Mahwah, NJ: Lawrence Erlbaum Associates.

Helms, J. E. (1990). Black and White racial identity: Theory, research and practice. Westport: CT: Greenwood Press.

Herrnstein, R. J., \& Murray, C. (1994). The bell curve: Intelligence and class structure in American life. New York: Free Press.

Hidalgo, N. M., Siu, S., \& Epstein, J. L. (2004). Research on families, schools, and communities: A multicultural perspective. In J. A. Banks (Ed.), Handbook of research on multicultural education (pp. 631-655). San Francisco: Jossey-Bass.

Hollins, E. R., \& Guzman, M. T. (2005). Research on preparing teachers for diverse populations. In M. Cochran-Smith \& K. M. Zeichner (Eds.), Studying teacher education: The report of the AERA panel on research and teacher education (pp. 477-548). Mahwah, NJ: Lawrence Erlbaum Associates.

Hurtado, A. (1995). Variations, combinations, and evolutions: Latino families in the United States. In R. Zambrana (Ed.), Understanding Latino families (pp. 40-61). Thousand Oaks, CA: Sage.

Jeynes, W. H. (2009). Family factors and the educational success of children. New York: Routledge.

Internal Environment. (2000). Retrieved March 20, 2007, from http://www.uga.edu/strategic planning/part2/8.html.

Irvine, J. J. (2003). Educating teachers for diversity: Seeing with a cultural eye. New York: Teachers College Press.

Janesick, V. J. (1994). The dance of qualitative research design: Metaphor, methodolatry and meaning. In N. K. Denzin \& Y. S. Lincoln (Eds.), Handbook of qualitative research (pp. 209219). Thousand Oaks, CA: Sage Publications.

Jarvie, I. C. (1969). The problem of ethical integrity in participant observation. Current Anthropology, 10(5), 505-508.

Jensen, A. R. (1998). The g factor: The science of mental ability. Westport, CT: Greenwood Publishing.

Johnson, L. (2002). "My eyes have been opened": White teachers and racial awareness. Journal of Teacher Education, 53(2), 153-167.

Jones, M. G., \& Carter, G. (2007). Science teacher attitudes and beliefs. In S. K Abell \& N. G. Lederman (Eds.), Handbook of research on science education (pp. 1067-1104). Mahwah, NJ: Lawrence Erlbaum Associates.

Kincheloe, J. L., \& McLaren, P. L. (1994). Rethinking critical theory and qualitative research. In N. K. Denzin \& Y. S. Lincoln (Eds.), Handbook of qualitative research (pp. 138-157). Thousand Oaks, CA: Sage Publications.

Kincheloe, J. L., \& McLaren, P. L. (2005). Rethinking critical theory and qualitative research. In N. K. Denzin \& Y. S. Lincoln (Eds.), The Sage handbook of qualitative research (pp. 303-342). Thousand Oaks, CA: Sage Publications.

Ladson-Billings, G. (1994). The dreamkeepers: Successful teachers of African American children. San Francisco: Jossey-Bass.

Ladson-Billings, G. (2004). New directions in multicultural education: Complexities, boundaries, and critical race theory. In J. A. Banks \& C. A. M. Banks (Eds.), Handbook of research on multicultural education (p. 50-68). San Francisco: Jossey-Bass. 
LeCompte, M. D., \& Preissle, J. (1993). Ethnography and qualitative design in educational research. San Diego, CA: Academic Press.

Lee, C. D., \& Slaughter-Defoe, D. T. (2004). Historical and sociocultural influences on African American Education. In J. A. Banks \& C. A. M. Banks (Eds.), Handbook of research on multicultural education (pp. 462-490). San Francisco: Jossey-Bass.

Lee, O., \& Luykx, A. (2007). Science education and student diversity: Race/ethnicity, language, culture, and socioeconomic status. In S. L-K.. Abell \& N. G. Lederman (Eds.), Handbook of research on science education (pp. 171-198). Mahweh, NJ: Lawrence Erlbaum Associates.

Lincoln, Y. S., \& Denzin, N. K. (1994). The fifth moment. In N. K. Denzin \& Y. S. Lincoln (Eds.), Handbook of qualitative research (pp. 575-586). Thousand Oaks, CA: Sage Publications.

Loughran, J. J. (2007). Science teacher as learner. In S. L. Abell \& N. G. Lederman (Eds.), Handbook of research on science education (pp. 1043-1066). Mahweh, NJ: Lawrence Erlbaum Associates.

Lowenstein, K. L. (2009). The work of multicultural teacher education: Reconceptualizing the White teacher candidates as learners. Review of Educational Research, 79(1), 163-196.

Luft, J. A. (2001). Changing inquiry practices and beliefs: The impact of inquiry-based professional development programmed on beginning and experienced secondary teachers. International Journal of Science Education, 23, 517-534.

Martin, O., \& Williams-Dixon, R. (1994). Overcoming social distance barriers: Preservice teachers' perceptions of racial ethnic groups. Journal of Instructional Psychology, 21(1), 76-82.

McLaren, P. (1995). Life in schools. New York: Longman.

Metz, M. H. (1986). Different by design: The context and character of three magnets schools. New York: Routledge.

Milner, H. R. (2003). Teacher reflection and race in cultural contexts: History, meanings, and methods in teaching. Theory into Practice, 42(3), 173-180.

Munby, H., Russell, T., \& Martin, A. K. (2001). Teachers' knowledge and how it develops. In V. Richardson (Ed.), Handbook of research on teaching (pp. 877-906). Washington, DC: American Educational Research Association.

Nieto, S. (1992). Affirming diversity: The sociopolitical context of multicultural education. White Plains, NJ: Longman.

Parsons, E. C. (2000). Culturalizing science instruction: What is it? What does it look like? Why do we do need it? Journal of Science Teacher Education, 11, 207-219.

Patton, M. Q. (1990). Qualitative evaluation and research methods. Newbury Park, CA: Sage Publications.

Peng, S. S., Wright, D., \& Hill, S. T. (1995). Understanding racial-ethnic differences in secondary science and mathematics achievement (Report and Development Report, February 1995.) Washington, DC: National Center for Education Statistics, U. S. Office of Education. Retrieved October 31, 2009 from $\mathrm{http} / /$ books.google.com/books?hl=en\&lr=\&id=rx5coDGO9sC\&oi=fnd\&pg=PR4\&dq=racial+c omposition+of+science+teachers, $+2000 \&$ ots $=48$ XJD2y6xg\&sig=MHSLC3 vFkfJWi6eRKDsR JT $82 \mathrm{mdc} \# \mathrm{v}=$ onepage $\& \mathrm{q}=\& \mathrm{f}=$ false

Ponterotto, J. G., Casas, J. M., Suzuki, L. A., \& Alexander, C. M. (Eds.). (1995). Handbook of multicultural counseling. Thousand Oaks, CA: Sage.

Richardson, V., \& Placier, P. (2001). Teacher change. In V. Richardson (Ed.), Handbook of research on teaching (pp. 905-947). Washington, DC: American Educational Research Association.

Rotheram, J., \& Phinney, J. (Eds.). (1987). Children's ethnic socialization: Pluralism and development. Beverly Hills, CA: Sage Publications.

Ruiz, A. L. (2002). Wanted: Teachers with conciencia. In L. Darling-Hammond, J. French, \& S. P. Garcia-Lopez (Eds.), Learning to teach for social justice (pp. 192-200). New York: Teachers College Press. 
Sleeter, C. (1992). Restructuring schools for multicultural education. Journal of Teacher Education, 43(2), 141-148.

Sleeter, C. (2001a). Epistemological diversity in research on preservice teacher preparation for historically underserved children. In W. Secada (Ed.), Review of research in education (pp. 209-250). Washington, DC: American Educational Research Association.

Sleeter, C. (2001b). Preparing teachers for culturally diverse schools: The overwhelming presence of Whiteness. Journal of Teacher Education, 52(2), 94-106.

Sleeter, C. E., \& Grant, C. A. (2007). Making choices for multicultural education: Five approaches to race, class, and gender. Hoboken, NJ: John Wiley \& Sons.

Smith, P. J. (1992). Representing the Other: 'Race', text, and gender in Spanish and Spanish American Narratives. Oxford: Clarendon Press.

Solomon, P., Portelli, J., Daniel, B., \& Campbell, A. (2005). The discourse of denial: How white teacher candidates construct race, racism, and 'White privilege.' Race, Ethnicity, and Education, 8(2), 147-169.

Spencer, D. A. (2001). Teachers' work in historical and social context. In V. Richardson (Ed.), Handbook of research on teaching (803-825). Washington, DC: American Educational Research Association.

Spring, J. (2004). American education with powerweb. New York: McGraw-Hill.

Stake, R. E. (1994). Case studies. In N. K. Denzin \& Y. S. Lincoln (Eds.), Handbook of qualitative research (pp. 236-247). Thousand Oaks, CA: Sage Publications.

State Governor's Office of Student Achievement. (2007). Retrieved March 20, 2007, from http://reportcard.gaosa.org.

Tajfel, H. (1978). The social psychology of minorities. New York: Minority Rights Group.

Tatto, M. T. (1998). The influence of teacher education on teachers' experiences, beliefs, and classroom practices. Journal of Teacher Education, 49, 66-77.

Thomson, N., Wilder, M., \& Atwater, M. M. (2001). Critical multiculturalism and secondary teacher education programs. In D. Lavoie (Ed.), Models for science teacher preparation: Bridging the gap between research and practice, 195-211. New York: Kluwer Publishers.

Traudt, K. (2002). Survey says...: Can White teachers effectively teach students of color? In L. Darling-Hammond, J. French, \& S. P. Garcia-Lopez (Eds.), Learning to teach for social justice (pp. 43-51). New York: Teachers College Press.

Villegas, A. M. \& Lucas, T. (2002). Educating culturally responsive teachers: A coherent approach. Albany, NY: State University of New York.

Wayne, A. J., \& Young, P. (2003). Teacher characteristics and student achievement gains: A review. Review of Educational Research, 73(1), 89-122.

Wei-Cheng, M. (1997). Parental influences on the high school students' academic achievement: A comparison of Asian immigrants, Asian Americans, and White Americans. Psychology in the Schools, 34(3), 267-277.

Weiner, L. (1993). Preparing teachers for urban schools: Lessons from 30 years of school reform. New York: Teachers College Press.

Weiner, L. (2000). Research in the 90s: Implications for urban teacher preparation. Review of Educational Research, 70(3), 369-406.

West, C. (1993). Race matters. Boston: Beacon.

Zeichner, K. (1992). Educating teachers for cultural diversity. East Lansing, MI: National Center for Research on Teacher Learning.

Zeichner, K. M., \& Hoeft, K. (1996). Teacher socialization for cultural diversity. In J. Sikula, T. Buttery, \& E. Guyton (Eds.), Handbook of research on teacher education (pp. 525-547). New York: Macmillan.

Zint, M. (2002). Comparing three attitude-behavior theories for predicting science teachers' intentions. Journal of Research in Science Teaching, 39, 819-844. 


\section{Atwater et al.,}

\section{Authors}

Mary M. Atwater is a professor of science education in the Office of Research, College of Education, at the University of Georgia. She holds a Ph.D. in science education and master's and bachelor degrees in chemistry. She is an inaugural fellow of the American Educational Research Association and a fellow of the American Association for the Advancement of Science. Her research focuses on socio-cultural-political factors that influence science teaching and learning. Correspondence: University of Georgia, College of Education, Office of Research, 376 Aderhold Hall, Athens, GA 30602-6007, USA. E-mail: atwater@uga.edu

Tonjua B. Freeman is a Ph.D. candidate in the Science Education Program at The University of Georgia. She has a M. Ed. in Science Education from The University of Georgia and a B.S. in Science Teaching/Biological Sciences from Clemson University. Her dissertation explores the techniques employed by high school science teachers that help to increase the achievement levels of their Black students. Her contact information is as follows: The University of Georgia, Department of Mathematics and Science Education, 212 Aderhold Hall, Athens, GA 306027126, USA. E-mail: tbf@uga.edu

Malcolm B. Butler is an Associate Professor of Science Education at the University of South Florida in St. Petersburg, Florida. He earned his Ph.D. (1995) in Science Education from the University of Florida, USA. His research interests include multicultural science teacher education, writing to learn in science, and science content for elementary teachers.

E-mail: mbbutler@mail.usf.edu

Jessie Draper-Morris graduated from The University of Georgia in 2000 with a B.S. Ed. and in 2005 with an M.A. Ed. in science education. She is currently a doctoral student at UGA in the Science Education Program focusing in inquiry in the context of biology teaching. She currently teaches advanced high school biology courses in the greater Atlanta-Metro area. Her contact information is as follows: The University of Georgia, Department of Mathematics and Science Education, 212 Aderhold Hall, Athens, GA 30602-7126, USA. E-mail: draper@uga.edu. 


\section{Appendix}

Description of the Six Interview Protocols

\section{Phase A}

First Interview Protocol - Life Experiences

Describe the community or communities in which you have lived

Describe your family

What comes to mind when you hear the word "diversity" used to describe people? What are some examples of diversity? What would you consider diversity to be at school?

What do you think culture means when it is used to describe human beings?

Do you think that cultures differ? If so, describe how and

give some examples? If you do not think they differ, why do you think this

way?

Describe your culture. Describe any experiences you might have had with people

who come from a different culture than yours?

What do you think ethnicity means when it is used to describe people? Give

some examples of ethnicity.

Describe your ethnicity. Describe any experiences you might have had with

people who come from a different ethnicity than yours.

What do you think race means when it is used to describe people? Do you believe that race should be used to describe human beings? If so, why? If not, why not?

Describe your race. Describe any experiences you might have had with people who come from a different race than yours.

\section{Second Interview Protocol - Educational Experiences}

Are you currently teaching? What school, grades, and subjects are you teaching this year? Can you describe the students in your classrooms?

What experiences if any in your education have you noticed that teachers have accommodated students from different cultures. Different races? Different ethnicities?

What do you think multicultural education is?

Do you think multicultural education should be a part of teacher preparation

programs? Why or why not?

Describe any educational experiences that have impacted on your views about

culture? Race? Ethnicity? Diversity?

Since you are planning to teach, do you plan to accommodate students from different cultures? Different races? Different ethnicities? If you do not, give your reasons for not accommodating students from different cultures? Different races? Different ethnicities? If you do, how do you plan to accommodate the students from different cultures? From different races? From different ethnicities?

Since you are teaching now, do you accommodate students from different cultures? Different races? Different ethnicities?

If you do not, what do you consider to be accommodations? What are your reasons for not accommodating students from different cultures? Different races? Different ethnicities? 
If you do, what do you do to accommodate students from different cultures? Different races? Different ethnicities?

\section{Third Interview Protocol - Programmatic Experiences}

What do you think makes students different from the teacher?

What are the ideas and concepts that were discussed in your Block I/PACSS classes this semester that were related to culture, race, ethnicity and science teaching?

Do you think that you Block I/PACSS classes have begun to prepare you to teach students who are different from you? Why or why not? How did Block I/PACSS prepare you?

What are some strategies you will use in your classroom in working with students who are different from you that you have learned in your Block I courses?

Is there anything else that you would like to share that would inform ... Department in its efforts to enhance its preparation of science teachers to work with students who are different from them?

Are there any additional experiences that you would like to have in your science education program to prepare you to teach students who are different from you? If so, what are they? If not, why?

\section{Phase B}

Fourth Interview Protocol

Describe the diversity of your students by class period.

How many mentor teachers did you have? Or do you still have?

How do you think your mentor teacher differs from you?

Tell me about your mentor teacher's philosophy of teaching students. Your perceptions of the mentor teacher's philosophy?

Can you describe to me your teaching philosophy?

Tell me how you are different from your students?

Do you think your student's race influences his or her ability to understand science concepts?

Describe any curriculum changes, if any that are being made by you to accommodate students' culture, ethnicity, or race by class period?

Describe any instructional strategies, if any that have been made by you to accommodate students' culture, ethnicity, and race by class period.

Fifth Interview Protocol

Describe curriculum changes, if any that you are making to accommodate students' culture, ethnicity, and race by class period.

Does your university supervisor or your university supervisor in the past share with you any instances in which you accommodate students based on their culture, ethnicity, or race?

Did your university supervisor share with you any instances in which you didn't accommodate students based on their ethnicity, culture, or race?

Sixth Interview Protocol 
Describe any class discussions, if any, about culture, ethnicity, race, and science teaching and learning that you had in Block II classes or your experience with PACSS.

Do you feel you are prepared to teach students who are different from you? Why or why not?

One of the goals of the science teacher education program is to prepare future teachers to teach students who are different from them. What recommendations do you have to help us achieve that goal? 


\title{
Fen öğretmen adaylarının "diğer” öğrencilerin kültürel olarak duyarlı öğretimine ilişkin anlaması ve filleri ile bağlantılı bir vaka çalışması
}

\author{
Eleştirel teoriyi bir felsefi lens olarak kullanan bu açıklayıcı vaka çalışması, iki fen \\ öğretmen adayının diğerlerini anlamasını ve onları diğerleri şeklinde algılayan öğrencilerin \\ kültürel olarak duyarlı öğretimine (veya diğerlerinin yokluğu) odaklanmıştır. \\ Araştırmacılar, katılımcıların öğrencileri için farklı amaçlara rağmen öğrencilerinin kültürü, \\ ırkı ve/veya etnicitisi nedeni ile bazı öğrencilerine duyarlı olmadıklarını bulmuşlardır. \\ Katılımcıların her ikisi de fen öğretmen eğitimi programı bazı eksiklikleri olduğunu, diğer \\ öğrencilerin fen öğretiminde başarılı olması için ihtiyaç duydukları tüm tecrübeleri \\ sağlamadığına inanmaktadırlar.
}

Anahtar kelimeler: çok kültürlü fen öğretmeni eğitimi, kültürel olarak duyarlı öğretim, eleştirel teori, vaka çalışması 